\title{
Els models, organitzadors del currícul en biologia
}

\author{
Pilar Garcia Rovira \\ IES Joan Oliver (Sabadell) i Dep. de Didàctica de les Matemàtiques i les Ciències Experimentals, UAB \\ pilar.garcia@uab.es
}

Es presenta una proposta d'organització del currículum de biologia basada en determinats models teòrics. Hi justifiquem la seva idoneïtat $i$ validesa i presentem alguns dels resultats de la seva aplicació a l'aula.

\section{Què n'esperem, dels nostres alumnes, en biologia?}

Segurament que bona part de professors de Ciències Naturals pensen que l'aprenentatge dels conceptes biològics hauria de servir als alumnes per aprendre a explicar fets individualment $i$ socialment rellevants, com per exemple per què el linx ibèric o la tortuga mediterrània estan en perill d'extinció, per què els aliments es poden deteriorar, per què una estufa de butà pot provocar la mort de persones que dormen en una habitació tancada, per què cal usar els antibiòtics de forma responsable, valorar el risc que té una parella amb antecedents familiars de tenir un fill afectat per una malaltia hereditària o la importància de les cèl.lules mare per desenvolupar determinades teràpies.

No obstant això, tant l'anàlisi dels continguts dels textos escolars i de la seva seqüenciació, com els resultats obtinguts pels alumnes en avaluacions com el projecte PISA (OCDE, 2001) permeten qüestionar la validesa i adequació de les propostes tradicionals per aconseguir aquests objectius.

Per tal que els alumnes aprenguin a explicar fets del món com els esmentats anteriorment, fan falta canvis profunds a nivell curricular i metodològic.

Actualment es considera que un projecte d'ensenyament de les ciències "autèntic" s'ha de fonamentar en una idea de ciència coherent amb les acceptades pels filòsofs i historiadors de la ciència.

En aquest article partim de la hipòtesi que el model cognitiu de ciència (Giere, 1999) i la seva aplicació a l'activitat científica escolar (Sanmartí i al., 1999; Izquierdo, 2000) ofereixen un marc teòric i pràctic adequat per assolir l'objectiu proposat.
Per això volem proposar una organització del currículum de biologia basada en determinats models teòrics. Justificarem la seva idoneïtat i validesa i presentarem alguns dels resultats de la seva aplicació a l'aula.

\section{Un ensenyament de les ciències basat en models teòrics}

Molts autors consideren la Ciència com un coneixement basat en 'models teòrics'. Es parteix de la idea que les afirmacions teòriques sobre el món, per exemple les trames d'idees que ens serviran per caracteritzar els éssers vius, no procedeixen directament del món sinó que 'són objectes abstractes el comportament dels quals s'ajusta exactament als enunciats o definicions elaborats pels científics'. Però la seva relació amb el món real és complexa. 'L'ajust entre model i realitat no és global, sinó relatiu als aspectes del món que el model intenta capturar' (Giere, 1999). La relació entre el món i el model no és una relació de 'veritat' sinó més aviat d'ajust i de similitud.

Aquest model cognitiu de ciència permet, per una part, caracteritzar les activitats científiques escolars i elaborar materials didàctics fonamentats teòricament. I per una altra, és especialment adequat per als moments d'emergència i consolidació del coneixement científic, tant a nivell individual com social, com són les situacions d'aprenentatge.

En efecte, creiem que és idoni per a la classe de ciències ja que

a) el seu objectiu és interpretar teòricament el món i això és també el que dóna sentit a les 'autenti- 
ques' propostes sobre ensenyament de les ciències;

b) permet definir el 'millor model teòric és a dir el més adequat perquè l'alumnat pugui aprendre a explicar teòricament la realitat;

c) possibilita la utilització de diferents 'mètodes' per pensar i actuar de manera que serveixin a l'alumnat per arribar a dominar les teories científiques escolars $\mathrm{i}$

d) la seva validesa es basa en la seva significatividad per a l'alumnat, és a dir, el seu grau d'utilitat per aprendre a explicar teòricament el món.

\section{Els models teòrics com a organitzadors del currículum en biologia}

Els models teòrics utilitzats a l'aula han de ser pocs i significatius. En el cas de la biologia proposem aquests: ésser viu, cèl-lula, ecosistema i evolució (fig. 1).

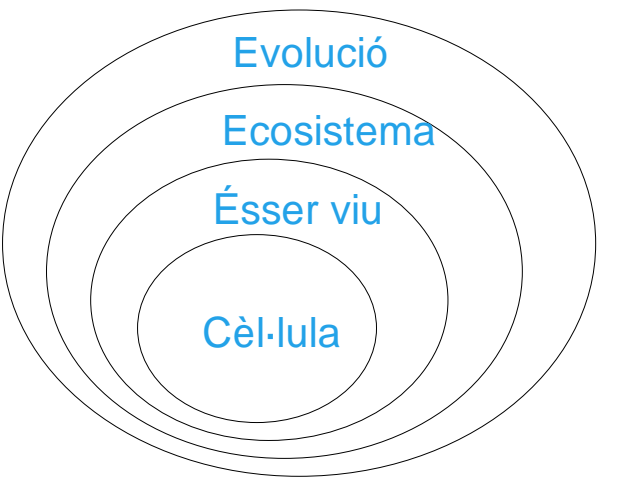

Figura 1. Cadascun dels models proposats inclouen l'anterior.

En realitat, cadascun d'aquests models constitueix una família de models que al seu torn funcionen com una teoria. Moltes vegades els continguts treballats a l'aula tenen sentit per al professorat però l'alumnat no és capaç d'establir relacions entre ells. Treballar a partir d'aquests models permet estructurar el currículum de manera que els diferents temes adquireixin significat per a l'alumnat, ja que apareixen interrelacionats.

Els científics, per parlar sobre les idees teòriques han inventat un llenguatge simbòlic i abstracte. Per exemple parlen de les funcions de nutrició, relació i reproducció i d'estructura cel-lular com les característiques pròpies dels éssers vius que els distingeixen dels objectes mancats de vida.

Els experts associen la paraula nutrició al conjunt de processos mitjançant els quals els éssers vius, des dels bacteris fins als animals, poden ob- tenir matèries primeres i energia per a la vida. Aquest concepte, construït al llarg de molts anys d'investigacions, l'han creat els científics per referirse de manera generalitzada al conjunt de processos (digestió interna i externa, fotosíntesi, respiració aeròbia i anaeròbia) que realitzen els diferents grups d'éssers vius per intercanviar matèria i energia amb el medi. Tots aquests significats estan inclosos, doncs, en el concepte i en la paraula nutrició.

Anàlogament podríem argumentar que els significats de cadascuna de les paraules utilitzades per definir la vida són també d'una gran complexitat. Encara que els alumnes pot ser que les aprenguin $i$ les repeteixin, això no vol dir que imaginin alguna cosa semblant al que en pensa el professorat.

No obstant això, si volem que els alumnes aprenguin ciències per poder explicar per què la floridura del pa o els bacteris del iogurt són vius, no n'hi ha prou amb haver memoritzat la definició de ésser viu, sinó que farà falta reconstruir amb ells a l'aula el model 'ésser viu'.

En aquesta proposta el model 'ésser viu' s'entén com un sistema complex que:

- intercanvia matèria i energia amb el medi i en fer-ho modifica el medi (equival al concepte de nutrició construït pels científics),

- capta estímuls del medi, i respon a aquests (es correspon amb el concepte de relació tal com apareix formulat en els texts científics per a universitaris),

- prové d'altres éssers vius i pot reproduir-se i transferir les seves característiques als seus descendents (recull la idea d'autoperpetuació que serveix per caracteritzar la vida),

- i està constituït per una o moltes unitats estructurals que anomenem cèl-lules, cadascuna amb les mateixes propietats que el tot (es correspon amb la teoria cel.lular).

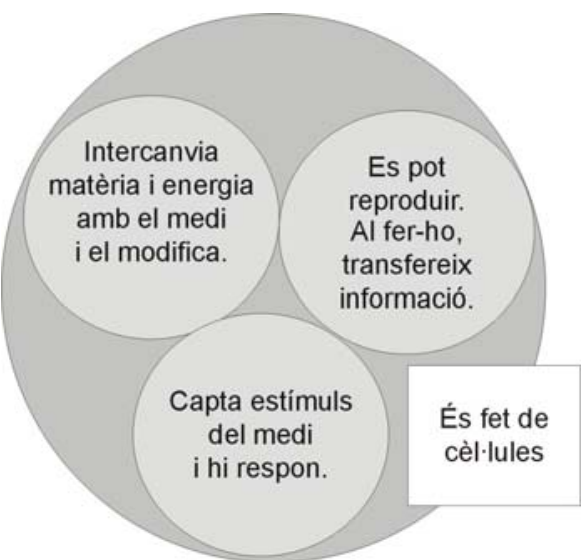

Figura 2. Principals components del model 'ésser viu'. 
D'altra banda considerem que no és possible imaginar les 'maneres de viure' de forma descontextualitzada sinó en constant interrelació amb el medi ambient.

L'aplicació d'aquest model a l'estudi de diversos éssers vius, des dels animals als bacteris, permet aprofundir en la construcció de cadascun d'aquests enunciats que configuren el model 'ésser viu' $i$, alhora, aprendre a mirar la diversitat, no com una diversitat de formes (aproximació pròpia de la sistemàtica i la taxonomia biològica), sinó com una diversitat de maneres de viure, és a dir de realitzar les funcions pròpies de la vida (Margulis i Sagan, 1997).

En general els llibres de text dediquen una lliçó a l'estudi de la cèl.lula i de la teoria cel.lular. Moltes vegades en un parell de pàgines s'introdueix no sols l'organització eucariota (animal i vegetal) sinó també la procariota.

Analitzant-ne el contingut s'arriba a la conclusió que el principal objectiu és que l'alumnat memoritzi una quantitat ingent de noms que no li aporten més coneixement que el purament enciclopèdic. Una vegada més el problema és, per una part, que els nois i noies no són experts $i$ en conseqüència no poden fer seves, una vegada per totes, idees tan importants en el camp de la biologia. I d'altra banda, que la selecció de continguts potser no sigui la més adequada per propiciar la construcció del concepte de cèl.lula com a unitat de vida, ni el de diversitat a nivell cel.lular.

Pensem que la construcció d'aquest concepte requereix treballar el 'model cèl-lula', imaginant-les vives $\mathrm{i}$ aprenent a relacionar les seves parts amb els enunciats corresponents. A més, perquè els $a-$ lumnes aprenguin 'a mirar i a veure' les cèl.lules com a unitats 'vives' que formen els animals, les plantes... hem de parlar-ne en aplicar el model ésser viu a cadascun dels grups d'organismes, aprenent a relacionar la seva diversitat morfològica amb les funcions específiques que realitzen en els pluricel.lulars.

Per exemple, en un primer nivell estudiem els òvuls i espermatozoides i aprenem explicar la seva morfologia en relació amb a funció de reproducció. En estudiar les plantes parlem de les cèl.lules fotosintetitzadores i d'altres cèl.lules que no fan aquesta funció i les comparem a nivell estructural. Més endavant, en estudiar les persones parlarem de cèl-lules secretores, ciliades, neurones... ubicantles als diferents òrgans i relacionant en cada cas la seva morfologia, estructura i funció.

Treballant d'aquesta forma, tant horitzontalment durant un curs com transversalment al llarg dels diferents cursos de secundària i batxillerat, es posa de manifest que aquests models van adquirint sig- nificat per als alumnes a mesura que s'apliquen a contextos diversos i s'usen per interpretar diferents fets del món. D'altra banda la seva utilització al llarg de l'escolarització permet aprofundir en la construcció de significats que progressivament s'enriqueixen, alhora que es fan més complexos i abstractes.

En efecte, si abordem l'estudi de les persones amb el mateix model 'ésser viu' podem aprofundir en la construcció de cadascun dels enunciats de tal forma que creixin i s'enriqueixin adquirint més significat. D'aquesta forma els alumnes aprenen a explicar que les persones (fig. 3), per a intercanviar matèria i energia amb el medi:

- Digerim els aliments que es transformen en nutrients, que per poder respirar obtenim oxigen mitjançant els pulmons, que els nutrients i l'oxigen són transportats a totes i cadascuna de les cèl-lules del nostre cos i que és a cada una de les cèl-lules on en respirar s'utilitza l'oxigen per transferir energia dels nutrients a la cèl.lula. A més, tant els pulmons com els ronyons ens serveixen per retornar al medi productes de rebuig.

- Anàlogament, en estudiar les funcions de relació i reproducció en les persones, relacionantles amb les entitats corresponents del 'model ésser viu' aquest s'aprofundeix i s'amplien els seus significats, així com la capacitat d'establir noves relacions entre ells.

- La teoria cromosòmica de l'herència s'inscriu en el model reproducció i ambdós formen part de la família de models 'ésser viu'.

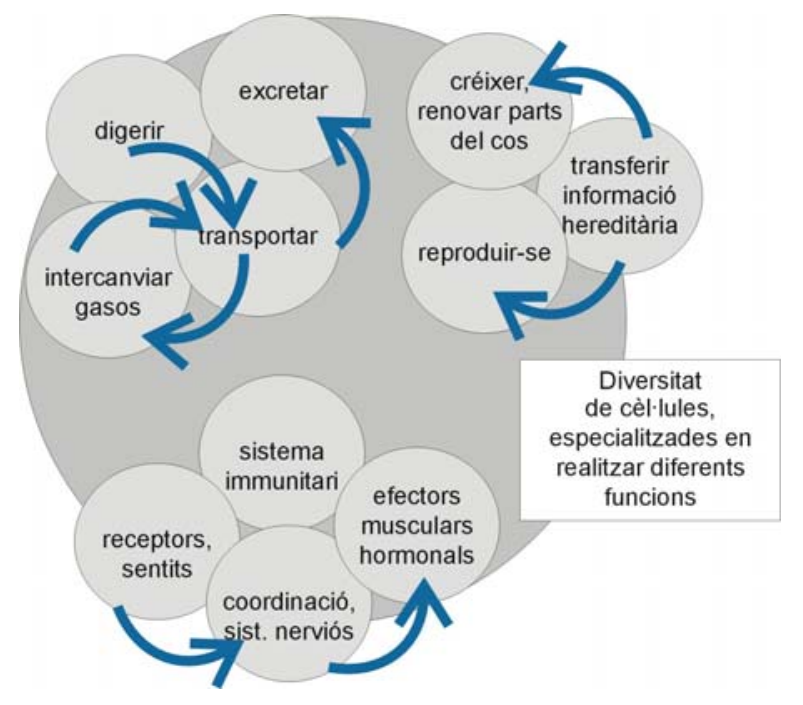

Figura 3. Model biològic de persona.

És com si després d'un pla general realitzéssim successius zooms d'un mateix paisatge. Cada nou enfocament permetrà conèixer-lo millor però sense 
perdre mai de vista el pla general que ens permet interpretar el conjunt.

D'acord amb el model cognitiu de ciència, considerem que cadascun dels fets interpretats a partir del model, juntament amb les activitats realitzades a l'aula per a la seva construcció, funciona com una hipòtesi teòrica del fenomen, alhora que aquest passa a formar part del propi model, enriquint-lo.

En funció d'aquests plantejaments, si ens situem en el model 'ecosistema', utilitzem les mateixes entitats teòriques; però la unitat bàsica en aquest cas no és l'organisme, sinó la població.

Cadascuna d'aquestes poblacions també (fig. 4)

a) intercanvia matèria i energia amb el medi (als manuals d'ecologia s'hi refereixen com a cicle de la matèria i flux d'energia),

b) es relaciona amb el medi i hi respon, modificantlo, dins de les limitacions del que entenem per adaptació (i ofereix un marc per interpretar totes les interaccions a nivell de biòtop i biocenosi així com els impactes ambientals i les seves conseqüències per a la població), i

c) es reprodueix i transfereix informació en l'espai i el temps (successions, fluctuacions...)

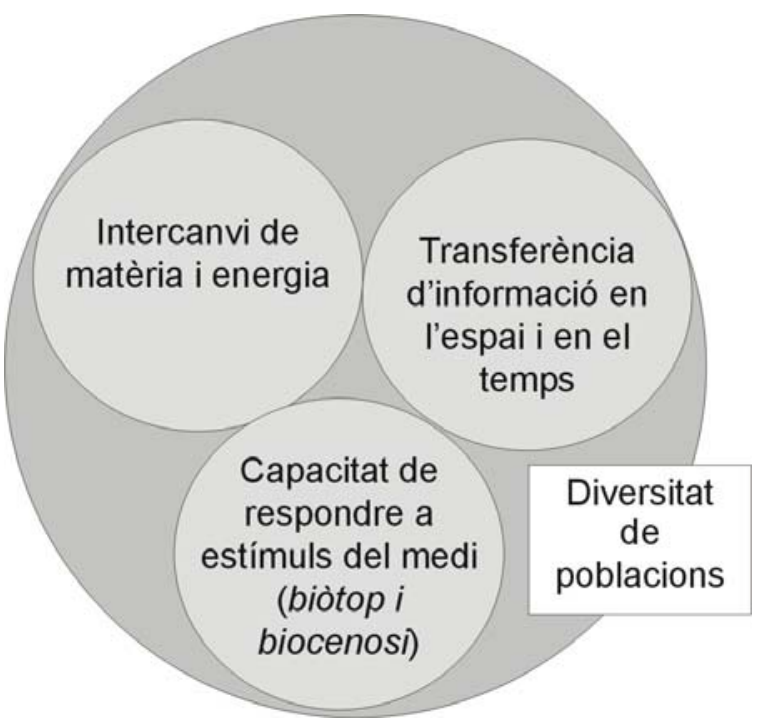

Figura 4. Principals components del model 'ecosistema'.

Finalment en el model evolució el sistema és tota la biosfera, constituïda per una gran diversitat d'éssers vius, les espècies, en un medi en constant modificació originada, sobretot, per la seva pròpia activitat metabòlica. Les entitats construïdes per explicar l'evolució són:
- els canvis al material hereditari com a origen de la variabilitat,

- la capacitat de transferir aquests canvis en sentit vertical (reproducció diferencial) i horitzontal (parasexualitat, simbiogènesi), i

- l'adaptació, entesa com a supervivència diferencial partint de la capacitat de resposta a les variacions del medi.

Aquesta proposta s'ha desenvolupat com una tasca d'investigació en l'acció al llarg de diversos cursos escolars. Paral-lelament s'han dissenyat estratègies perquè els alumnes aprenguin a modelitzar.

\section{Aprendre a modelitzar, a tall de conclusió}

Ensenyar ciència a l'escola implica ajudar l'alumnat a construir models que els resultin significatius.

Aquests models seran rellevants si connecten amb fenòmens familiars sobre els quals puguin pensar, parlar i actuar. Pensar a través de models suposa establir relacions entre 'allò real' i 'allò construït' i desenvolupar una visió multicausal, considerant simultàniament més d'una variable, amb la finalitat de poder predir i explicar. Anomenem modelització al procés de construcció d'aquestes relacions que considerem clau per aprendre ciències, ja que amb elles els alumnes aprenen a 'donar sentit' als fets del seu món, utilitzant models cada vegada més complexos.

S'ha fet un estudi de cas per valorar la capacitat de l'alumnat per elaborar explicacions de tipus argumentatiu, com a indicador d'aquesta capacitat d'establir relacions entre les evidències, 'allò real' i els models, 'allò construït'. Els resultats mostren que, encara que no es pot pretendre que tota la classe parli del fenomen de la mateixa manera ni al mateix nivell, sí que és possible aconseguir que tots progressin en la manera d'explicar (Sanmartí, 2003), usant com a referent el model de l'expert.

\section{Bibliografia}

GARCIA ROVIRA, M.P., Modelitzar fenòmens: una combinació de gèneres lingüístics. A Sanmarti, N. (coord.) (2003). Aprendre Ciències tot aprenent a escriure Ciència. Barcelona: Ed. 62.

GIERE, R. (1999). Un nuevo marco para enseñar el razonamiento científico. Enseñanza de las ciencias, Número Extra, 63-70. 
IZQUIERDO, M. (2000). Fundamentos epistemológicos. En: Perales, F. J., Cañal, P. (coords), Didáctica de las ciencias experimentales. Alcoy: Editorial Marfil, 35-64.

OCDE (2001). La medida de los conocimientos y destrezas de los alumnos. La evaluación de la lectura, las matemáticas y las ciencias en el Proyecto PISA 2000. Madrid: INCE.
Margulis i Sagan (1997). Qué es la vida? Barcelona: Tusquets.

SANMARTI, N., IZQUIERDO, M., GARCIA, P. 1999. Hablar y escribir. Una condición necesaria para aprender ciencias. Cuadernos de Pedagogía, 281, pp. 54-58. 